Article

\title{
Evaluation of nutritional methods to reactivate preserved ruminal inoculum assessed through in vitro fermentation kinetics and forage digestibility
}

María G. Domínguez-Ordóñez ${ }^{\text {a }}$

Luis A. Miranda-Romero ${ }^{\text {a }}$

Pedro A. Martínez-Hernández ${ }^{\mathrm{a}}$

Maximino Huerta-Bravo ${ }^{a}$

Ezequias Castillo-Lopez ${ }^{\text {b* }}$

${ }^{a}$ Universidad Autónoma Chapingo. Departamento de Zootecnia, 56220. Texcoco, Estado de México, México.

b Universidad Nacional Autónoma de México. Facultad de Estudios Superiores Cuautitlán, Medicina Veterinaria y Zootecnia. Cuautitlán, Estado de México, México.

*Corresponding author: ezequias@ huskers.unl.edu

\begin{abstract}
:
This study evaluated the effect of the media and pre-incubation time for reactivating preserved ruminal inoculum, assessed through in vitro fermentation kinetics and dry matter digestibility (IVDMD). In the first experiment, treatments were 1) CONTROL, fresh ruminal fluid, 2) LOW24, inoculum reactivated by $24 \mathrm{~h}$ pre-incubation in a basal culture solution, 3) MODE24, inoculum reactivated by $24 \mathrm{~h}$ pre-incubation in basal culture solution, yeast extract and peptone from casein; and 4) HIGH24, inoculum reactivated by $24 \mathrm{~h}$ pre-incubation in basal culture solution, yeast extract, peptone from casein and carbohydrates. In the second experiment, treatments evaluated were 1) CONTROL, fresh ruminal fluid, and 2) HIGH12, similar to HIGH24 but inoculum was pre-incubated for $12 \mathrm{~h}$. Each experiment included three replicates. Maximum gas volume $(V m)$, lag phase $(L)$, gas production rate $(S)$ and IVDMD were measured using four fermentation substrates. Main effects of inoculum and fermentation substrate, and interactions, were analyzed. Compared to CONTROL, $V m, L$ and $S$ were negatively affected $(P<0.01)$ by preservation of inoculum. However, HIGH24 displayed an


improvement $(P<0.01)$ in fermentation kinetics and IVDMD compared to MODE24 or LOW24. In the second experiment, HIGH12 displayed lower $(P<0.01)$ IVDMD at $72 \mathrm{~h}$ compared to CONTROL. Alfalfa and orchardgrass had higher $(P<0.01) \mathrm{Vm}$ and IVDMD compared to cocuite and guinea grass. Overall, reactivation of preserved ruminal inoculum by pre-incubation for $24 \mathrm{~h}$ in a medium containing yeast extract, peptone from casein and carbohydrates performed better compared to reactivation by pre-incubation for $12 \mathrm{~h}$; however, fermentation kinetics and IVDMD were still depressed compared to fresh ruminal fluid.

Key words: Forage digestibility, Fermentation, Preservation, Ruminal inoculum.

Received: 09/05/2017

Accepted: 08/03/2018

\section{Introduction}

In vitro techniques are commonly used to evaluate fermentation and digestibility of feed ingredients utilized in ruminant rations ${ }^{(1,2,3)}$. However, the need for fistulated animals for ruminal fluid collection is an important limitation of these techniques ${ }^{(4,5,6)}$. Thus, preservation of ruminal fluid might overcome this limitation as it allows the use of inoculum without having to keep donor animals ${ }^{(7,8,9)}$. This is conducted by using glycerol to minimizes microbial cell damage ${ }^{(10,11,12)}$ and maintain the microbial community ${ }^{(13,14)}$.

The appropriate reactivation of preserved inoculum before being used remains largely unknown. Lyophilized ruminal fluid underestimates in vitro fermentation and dry matter digestibility compared to fresh ruminal fluid when reconstituted in McDougall's buffer ${ }^{(8)}$. The depression in fermentation parameters ${ }^{(15)}$ presumably due to cell damage ${ }^{(8,9)}$ or microbial death ${ }^{(9)}$ may explain this underestimation. In addition, limitations in the availability of nutrients such as nitrogen ${ }^{(16,17)}$ and carbohydrates ${ }^{(18,19,20)}$ may influence reactivation, growth and activity of ruminal microbes. Thus, it has been recently acknowledged that the reactivation of preserved bacteria is a critical step in obtaining active microorganisms, and that the reactivation conditions should be optimized ${ }^{(21,22,23)}$.

Because of the limited information on strategies to improve the reactivation of ruminal inoculum, research to find a cost-effective and practical approach is warranted. Thus, the objectives of this study were to evaluate the effects of the culture medium used and the incubation time needed for proper reactivation of lyophilized ruminal inoculum. Response variables assessed were based on in vitro fermentation kinetics and dry matter digestibility of alfalfa, orchardgrass, cocuite and guinea grass. The hypothesis was that there will be no difference in in vitro forage digestibility and fermentation kinetics between preserved and fresh ruminal inoculum. 


\section{Material and methods}

Experiments were carried out at Universidad Autónoma Chapingo. Animals used in the experiments were managed according to the guidelines and University regulations.

\section{Fermentation substrates and chemical analysis}

Four forage species commonly used for grazing ruminants in Mexico were utilized as fermentation substrates (Table 1): alfalfa (Medicago sativa L) cv San Miguel, orchardgrass (Dactylis glomerata L) cv Potomac, cocuite (Gliricidia sepium (Jacq.) Kunth ex Walp.) and guinea grass (Panicum maximum Jacq.) cv Tanzania. Alfalfa, guinea grass and orchardgrass were cut at $7 \mathrm{~cm}$ above ground level; only leaves of cocuite were collected by hand from branches of several trees. Enough sample material was collected to obtain at least $1 \mathrm{~kg}$ of sample (DM basis) for each forage species. Collected forage samples were dried in a forced air oven at $60^{\circ} \mathrm{C}$ for $96 \mathrm{~h}$; they were ground to pass through a $1 \mathrm{~mm}$ screen (Wiley Mill, Arthur H. Thomas Co., Philadelphia, PA) and analyzed for crude protein, ash, ether extract ${ }^{(24)}$ (methods \# 976.06; \# 942.05; \# 920.39, respectively). Acid detergent fiber (ADF) ${ }^{(25)}$, neutral detergent fiber (NDF) were assayed without heat stable amylase and expressed inclusive of residual $\operatorname{ash}^{(25)}$, and soluble sugars ${ }^{(26)}$.

Table 1: Analyzed chemical composition ( $\mathrm{g} / \mathrm{kg} \mathrm{DM})$ of the four forage species used as fermentation substrates for in vitro fermentation kinetics and in vitro dry matter digestibility experiments

\begin{tabular}{lllllll}
\hline & \multicolumn{6}{c}{ Chemical composition (g/kg DM) } \\
\cline { 2 - 7 } Forage species & Crude protein & Ash & Ether extract ADF & NDF $^{\mathbf{A}}$ & Sugars \\
\hline Alfalfa & 206 & 119 & 11 & 350 & 442 & 41 \\
Orchardgrass & 197 & 163 & 26 & 400 & 540 & 35 \\
Cocuite & 183 & 85 & 24 & 367 & 465 & 47 \\
Guinea grass & 65 & 123 & 5 & 564 & 779 & 29 \\
\hline
\end{tabular}

$\mathrm{ADF}=$ acid detergent fiber; $\mathrm{NDF}=$ neutral detergent fiber.

${ }^{A}$ neutral detergent fiber was assayed without heat stable amylase and was expressed inclusive of residual ash.

\section{Ruminal fluid collection, preservation and reactivation}

In vitro procedures reported for each experiment included three replicates ${ }^{(27,28)}$. Similar to previous studies ${ }^{(29)}$, fresh ruminal fluid was collected for each in vitro run from three ruminally fistulated adult Creole rams with an average body weight of $53.0 \mathrm{~kg}$. Donor 
rams were fed a diet containing $80 \%$ forage and $20 \%$ concentrate. Feed was offered at 0900 and 1500 h every day; ad libitum intake was allowed. In addition, clean fresh water was available ad libitum. Rams were fitted with a ruminal cannula to collect ruminal fluid by suction ${ }^{(30)}$. The collected ruminal fluid was filtered through four layers of cheesecloth and equal volumes of ruminal fluid from each donor were combined in order to obtain a representative sample and to prevent animal-to-animal variations ${ }^{(31,32,33)}$.

Five percent (v/v) glycerol (Sigma-Aldrich, St. Louis, MO) was incorporated to serve as a cryoprotectant of ruminal inoculum ${ }^{(12,13)}$. Aliquots were placed in $10-\mathrm{mL}$ sterile glass containers. Containers were hermetically sealed and frozen at $-70{ }^{\circ} \mathrm{C}$ for $3 \mathrm{~d}$. Lyophilization was conducted as previously described ${ }^{(8)}$ (Labconco Lyph Lock, model $195)$ under vacuum $(-0.133 \mathrm{mBar})$, and inoculum was stored until later use. The reactivation of the preserved inoculum was conducted by reconstituting lyophilized samples in a cysteine solution to a volume equal to that of the original strained ruminal fluid. This solution contained $2.5 \mathrm{~g}$ of L-cysteine, $2.5 \mathrm{~g}$ of sodium sulfite and $0.1 \mathrm{~mL}$ of resazurin $(1 \%)$ dissolved in $15 \mathrm{~mL}$ of sodium hydroxide $(2 \mathrm{~N})$, distilled water was added to make a total volume of $100 \mathrm{~mL}$ (Table 2), which served as a buffer and created a reduced environment in the media, simulating the reduced conditions of the rumen. Reconstituted inoculum was incubated at room temperature for $10 \mathrm{~min}$ to allow rehydration, the reconstituted inoculum was transferred to $100 \mathrm{~mL}$ of culture medium, then it was pre-incubated at $39^{\circ} \mathrm{C}$ for 24 or $12 \mathrm{~h}$. The culture medium used and the preincubation time varied depending on the experiment, as described below.

Table 2: Ingredient composition of the three media utilized for the reactivation of lyophilized ruminal inoculum

\begin{tabular}{|c|c|c|c|}
\hline \multirow[b]{2}{*}{$\begin{array}{l}\text { Ingredient of medium used for } \\
\text { reactivation }\end{array}$} & \multicolumn{3}{|c|}{ Inoculum type } \\
\hline & LOW24 & MODE24 & HIGH24 \\
\hline & $\overline{----}$ & \multirow[t]{2}{*}{ Amount per $100 \mathrm{~mL}$} & \\
\hline & -- & & \\
\hline Distilled water, mL & 50 & 50 & 50 \\
\hline Ruminal fluid ${ }^{\mathrm{A}}, \mathrm{mL}$ & 29 & 29 & 29 \\
\hline $\begin{array}{l}\text { Sodium carbonate solution ( } 8 \%) \text {, } \\
\mathrm{mL}\end{array}$ & 5 & 5 & 5 \\
\hline Mineral solution $\mathrm{I}^{\mathrm{B}}, \mathrm{mL}$ & 7 & 7 & 7 \\
\hline Mineral solution $\mathrm{II}^{\mathrm{C}}, \mathrm{mL}$ & 7 & 7 & 7 \\
\hline Cysteine solution $^{\mathrm{D}}, \mathrm{mL}$ & 2 & 2 & 2 \\
\hline Resazurin solution $1 \%, \mathrm{~mL}$ & 0.10 & 0.10 & 0.10 \\
\hline Yeast extract, $\mathrm{g}$ & --- & 0.50 & 0.50 \\
\hline Peptone from casein, $\mathrm{g}$ & --- & 0.50 & 0.50 \\
\hline Ground forage $^{\mathrm{E}}, \mathrm{g}$ & 0.25 & 0.25 & 0.25 \\
\hline Glucose, $\mathrm{g}$ & --- & --- & 0.30 \\
\hline Cellobiose, $\mathrm{g}$ & --- & --- & 0.30 \\
\hline Starch, g & --- & --- & 0.25 \\
\hline
\end{tabular}




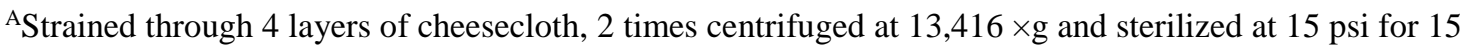
$\min$.

${ }^{\mathrm{B}}$ Containing $6.0 \mathrm{~g}$ of potassium hydrogen phosphate per liter of distilled water ${ }^{(44)}$.

${ }^{\mathrm{C}}$ Containing $6.0 \mathrm{~g}$ of monobasic potassium phosphate; $6.0 \mathrm{~g}$ ammonium sulfate; $12 \mathrm{~g}$ sodium chloride; $2.45 \mathrm{~g}$ magnesium sulfate monohydrate; and $1.6 \mathrm{~g}$ calcium chloride monohydrate per liter of distilled water $^{(44)}$.

D2.5 $\mathrm{g}$ of L-cysteine dissolved in $15 \mathrm{~mL}$ of sodium hydroxide $(2 \mathrm{~N}), 2.5 \mathrm{~g}$ of sodium sulfide and $0.1 \mathrm{~mL}$ of rezasurin $(1 \%)$ volume was brought to $100 \mathrm{~mL}$; the solution was heated and it was sterilized using an autoclave.

${ }^{\mathrm{E}}$ Ground guinea grass.
}

\section{Ruminal inocula evaluated}

Experiment 1. Four types of ruminal inoculum were evaluated for measurements of fermentation kinetics and IVDMD. A fresh ruminal fluid (Control) was compared to lyophilized inocula reactivated by pre-incubation for $24 \mathrm{~h}$ in 1 of 3 culture media (Table 2). Specifically, treatments were 1) CONTROL, fresh ruminal fluid; 2) LOW24, inoculum reactivated in a medium containing $100 \mathrm{~mL}$ of a basal culture solution (composed of $50 \%$ distilled water, $29 \%$ clarified ruminal fluid, $14 \%$ mineral solutions I and II, $5 \%$ sodium carbonate, $2 \%$ cysteine solution) and $0.1 \%$ resazurin; 3) MODE24, inoculum reactivated in a medium containing $100 \mathrm{~mL}$ of the basal culture solution, $0.1 \%$ resazurin, $0.5 \mathrm{~g}$ of yeast extract (Sigma-Aldrich, St. Louis, MO) and $0.5 \mathrm{~g}$ of peptone from casein (Bioxon Becton Dickinson, Mexico); and 4) HIGH24, inoculum reactivated in a medium containing $100 \mathrm{~mL}$ of a basal culture solution, $0.1 \%$ resazurin, $0.5 \mathrm{~g}$ of yeast extract (Sigma-Aldrich, St. Louis, MO), $0.5 \mathrm{~g}$ of peptone from casein (Bioxon Becton Dickinson, Mexico), $0.3 \mathrm{~g}$ of glucose, $0.3 \mathrm{~g}$ of cellobiose and $0.25 \mathrm{~g}$ of starch. Media also included $0.25 \mathrm{~g}$ of ground forage on a DM basis (Table 2).

Experiment 2. In the second experiment, two types of ruminal fluid were compared: 1) CONTROL, fresh ruminal fluid, and 2) HIGH12, inoculum reactivated using a medium previously described for HIGH24. However, in this experiment, preserved ruminal inoculum was reactivated by pre-incubation for only $12 \mathrm{~h}$ as an attempt to find a more practical and faster approach for the reactivation process.

\section{Fermentation kinetics and IVDMD}

In each experiment, fresh and reactivated ruminal inocula were combined with a diluting agent containing the reduced mineral solutions I and II and the cysteine solution ${ }^{(34)}$ at a ratio of 1:9 (v/v, ruminal fluid: diluting agent, Table 2). $\mathrm{CO}_{2}$ was flushed while adding the diluting agent to the ruminal fluid, which was maintained at $39^{\circ} \mathrm{C}$.

Afterwards, the fermentation kinetics and forage IVDMD were determined by combining $90 \mathrm{~mL}$ of diluted ruminal inoculum with $0.5 \mathrm{~g}$ of fermentation substrate using $125-\mathrm{mL}$ 
glass bottles. The determination of the parameters of fermentation kinetics was based on the procedure utilized for the measurement of gas $^{(35,36)}$. More specifically, gas pressure $\left(\mathrm{kg} / \mathrm{cm}^{2}\right)$ was recorded at 1, 2, 4, 6, 10, 14, 18, 24, 30, 38, 48 and $72 \mathrm{~h}$ of incubation. After recording this value at each time point, the gas pressure was reset to cero. The values of pressure were then converted to volume of gas ( $\mathrm{mL} / \mathrm{g} \mathrm{DM}$ of substrate); to do so, a standard curve was first generated by injecting known volumes of $\mathrm{CO}_{2}$. The equation of this standard curve was generated by adding a linear regression line, and this equation was: Gas volume $(\mathrm{mL} / \mathrm{g}$ of substrate $)=$ pressure $\left(\mathrm{kg} / \mathrm{cm}^{2}\right) * 39.46+0$, with an $\mathrm{R}^{2}$ of 0.94 . This standard curve was generated at room temperature. The use of this technique has also been recently reported by other investigators ${ }^{(29)}$.

The accumulated volume of gas at each time point was used to estimate the parameters of the fermentation kinetics: maximum volume of gas $(\mathrm{Vm} ; \mathrm{mL} / \mathrm{g})$, lag phase $(L ; \mathrm{h})$, and the rate of gas production $\left(S ; \mathrm{h}^{-1}\right)$. This was conducted using a logistic model described by Schofield et $a l^{(37)}$ :

$$
\text { Volume of gas }=\frac{V m}{1+\exp \left(^{(2-4 \times S \times(t-L))}\right.} \quad \text { (Equation 1) }
$$

\section{Where:}

$\boldsymbol{V m}$ is maximum volume;

$S$ is the rate of gas production;

$\boldsymbol{t}$ is the time point of measurement;

$\boldsymbol{L}$ is the lag phase.

In addition to parameters of fermentation kinetics, the IVDMD of substrates was determined at 24 and $72 \mathrm{~h}$ fermentation (IVDMD 24 , and IVDMD 72 , respectively). At each time point, the content of corresponding fermentation bottles was filtered through Whatman filter paper No. 4. The residue was dried at $100^{\circ} \mathrm{C}$ for $12 \mathrm{~h}$ in a forced air oven and the dry weight was recorded. Then, IVDMD was calculated relative to the amount of original sample used.

\section{Statistical analysis}

The GLM procedure of SAS ${ }^{(38)}$ was used. In each experiment $(\mathrm{n}=3)$, the mean values within each fermentation substrate were considered as the experimental unit. Given the controlled experimental conditions, significant effect was declared at $P<0.01$; this level of significance may also contribute to reduce the type I error risk. Only when first order interaction was not significant, mean separation for main effects was conducted by Tukey; otherwise, paired mean separation by $t$-test was performed. Dispersion parameter reported is the largest standard error of the mean (SEM).

Data from Exp 1 were analyzed as a completely randomized experimental design with a $4 \times 4$ factorial arrangement of treatments (4 inoculum types and 4 fermentation 
substrates). Data from Exp 2 were analyzed according to a completely randomized experimental design with a $2 \times 4$ factorial arrangement of treatments ( 2 inoculum types and 4 fermentation substrates). In both experiments, the main effects of inoculum type and fermentation substrate were analyzed. The interaction of inoculum type $\times$ fermentation substrate was also evaluated. The statistical model for the analyses was:

$$
\mathrm{Y}_{\mathrm{ijk}}=\mu+\tau_{\mathrm{i}}+\beta_{\mathrm{j}}+\tau \beta_{\mathrm{ij}}+\varepsilon_{\mathrm{ijk}}
$$

Where:

$\mathbf{Y}_{\mathbf{i j k}}$ represents the observation of the ijk treatment;

$\boldsymbol{\mu}$ represents the overall mean;

$\tau_{\mathbf{i}}$ represents the inoculum type $\mathrm{i}$;

$\boldsymbol{\beta}_{\mathrm{j}}$ represents the fermentation substrate $\mathrm{j}$;

$\tau \beta_{\mathbf{i j}}$ represents the interaction effect of the inoculum type $i$ and the fermentation substrate $\mathrm{j}$.

The residual term $\varepsilon_{i j k}$ was assumed to be normally, independently, and identically distributed, with variance $\sigma^{2}$.

\section{Results}

\section{Chemical composition of forages used as fermentation substrates}

Analyzed chemical composition of the four forages used is listed in Table 1. Guinea grass was low in crude protein and high in fiber contents $(65.0$ and $779.0 \mathrm{~g} / \mathrm{kg} \mathrm{DM}$ for crude protein and NDF, respectively); whereas alfalfa was high in protein and low in fiber content (206.0 and $442.0 \mathrm{~g} / \mathrm{kg} \mathrm{DM}$ for crude protein and NDF, respectively), with these nutrients having intermediate values for orchardgrass and cocuite.

\section{Fermentation kinetics and IVDMD for inocula reactivated by $24 \mathrm{~h}$ pre- incubation}

Figure 1 illustrates in vitro gas production for the CONTROL and inocula reactivated by pre-incubation for $24 \mathrm{~h}$. CONTROL displayed the fastest and greatest maximum gas production compared to the other treatments. Even with the HIGH24 treatment, fermentation was reduced by around $50 \%$ during the first hours of incubation. Within the preserved inocula, $\mathrm{HIGH} 24$ displayed the greatest maximum gas production, followed by MODE24 and by LOW24. In addition, Figure 2 displays gas production for each fermentation substrate. Alfalfa had the greatest and fastest maximum gas production 
compared to the rest of forages. Orchard grass displayed intermediate values for gas production, with cocuite and guinea grass having the lowest values.

Figure 1: In vitro gas production for the control and the preserved inocula reactivated by pre-incubation for $24 \mathrm{~h}$ in different culture media

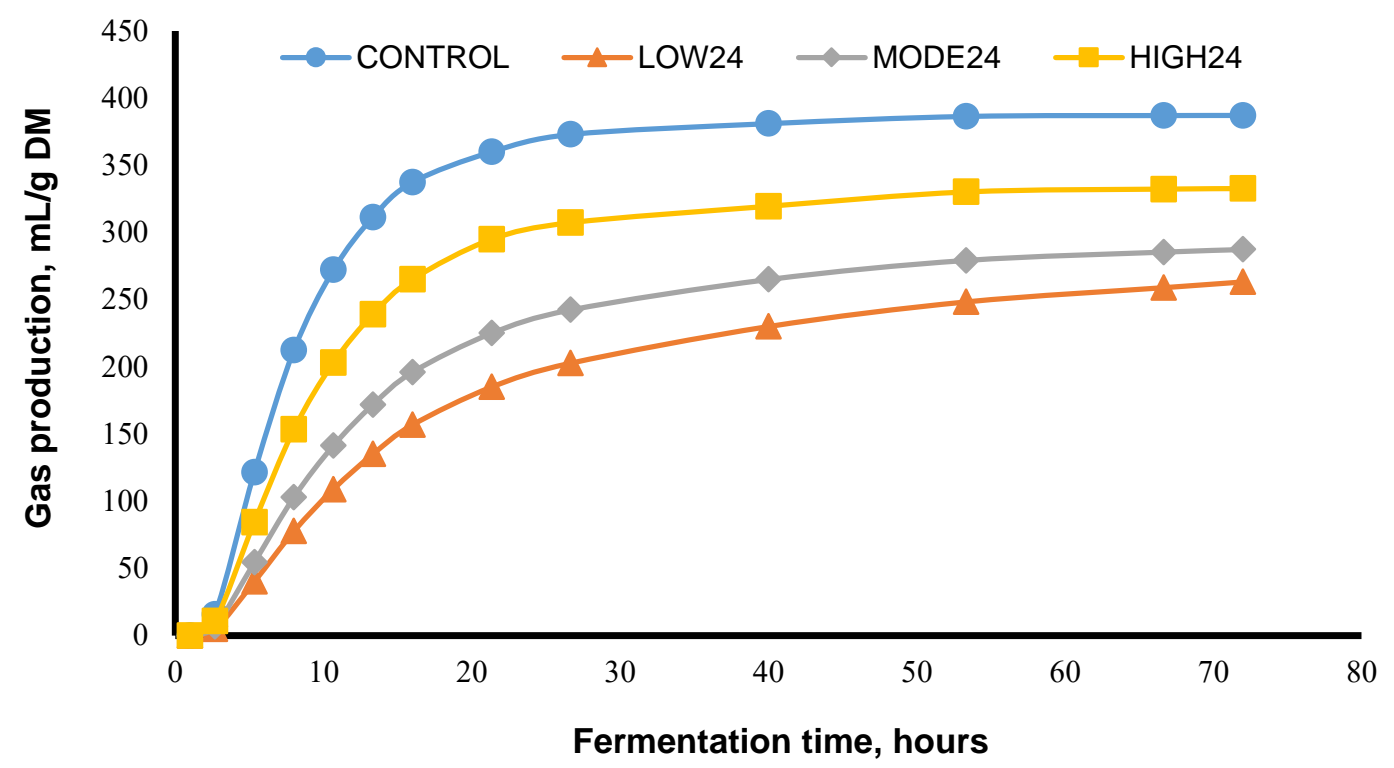

CONTROL= fresh ruminal fluid; LOW24= inoculum reactivated by $24 \mathrm{~h}$ pre-incubation in a basal culture solution; MODE24= similar to LOW24, but included yeast extract and peptone from casein; HIGH24= similar to MODE24, but included carbohydrates. Control: $V m=387.15 \mathrm{~mL} / \mathrm{g}, L=4.06 \mathrm{~h}, S=0.041 \mathrm{~h}^{-1}$; LOW24: $V m=266.11 \mathrm{~mL} / \mathrm{g}, L=13.70 \mathrm{~h}, S=0.018 \mathrm{~h}^{-1}$; MODE24: $V m=288.22 \mathrm{~mL} / \mathrm{g}, L=7.62 \mathrm{~h}, S=0.023 \mathrm{~h}^{-1}$; HIGH24: $V m=332.83 \mathrm{~mL} / \mathrm{g}, L=8.05 \mathrm{~h}, S=0.32 \mathrm{~h}^{-1}$. 
Figure 2: In vitro gas production for four forages when values for fresh ruminal fluid and inocula reactivated by pre-incubation for $24 \mathrm{~h}$ were averaged

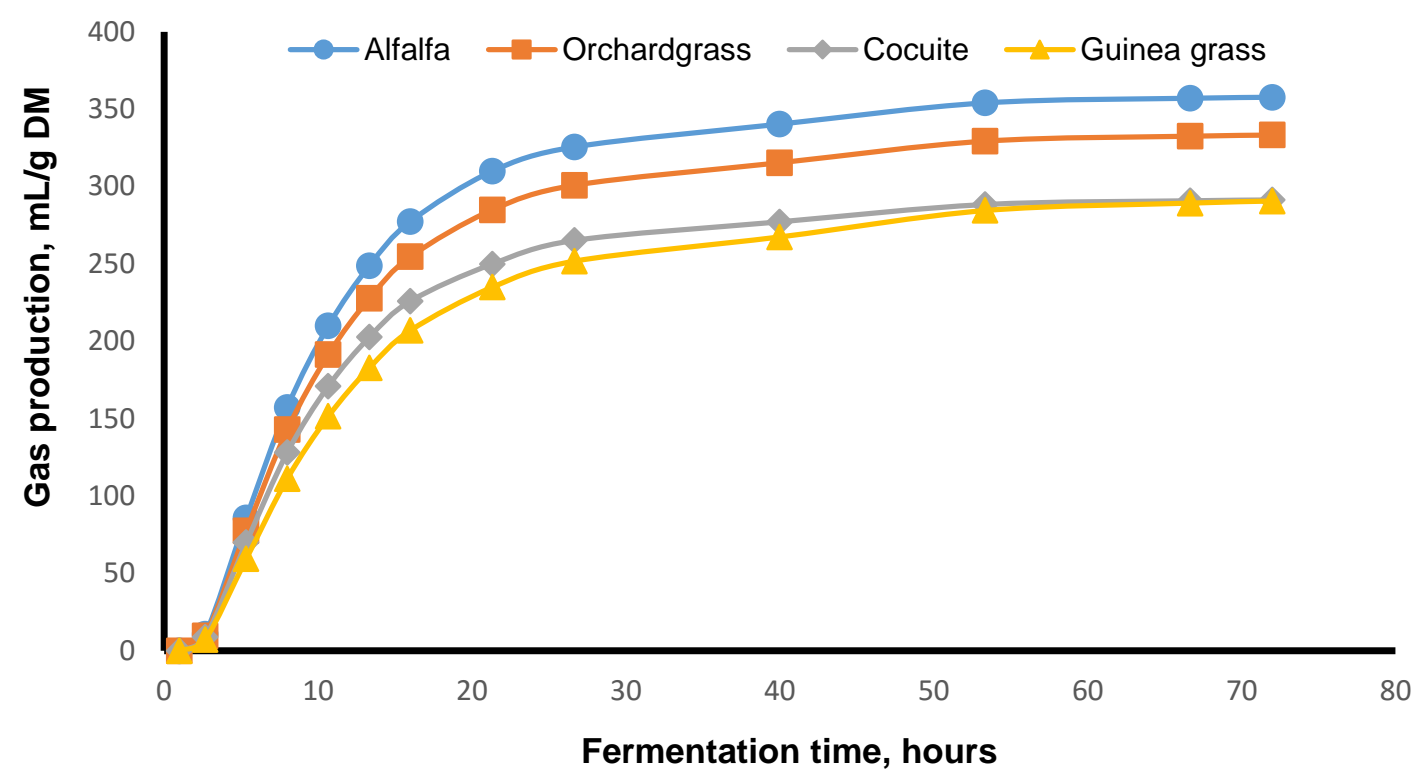

Alfafa: $V m=357.90 \mathrm{~mL} / \mathrm{g}, L=5.22 \mathrm{~h}, S=0.030 \mathrm{~h}^{-1}$; orchardgrass: $V m=333.50 \mathrm{~mL} / \mathrm{g}, L=11.77 \mathrm{~h}, S=0.029 \mathrm{~h}^{-1}$; cocuite: $V m=291.50 \mathrm{~mL} / \mathrm{g}, L=3.83 \mathrm{~h}, S=0.030 \mathrm{~h}^{-1}$; guinea grass: $V m=291.20 \mathrm{~mL} / \mathrm{g}, L=12.20 \mathrm{~h}, S=0.025 \mathrm{~h}^{-1}$.

More specifically, fermentation kinetics, IVDMD 24 and IVDMD 72 were affected by treatment and fermentation substrate (Table 3). Regardless of the nutrient composition of the medium used for reactivating the inoculum, $V m$ decrease $(P<0.01)$ when reactivated inoculum was used compared to fresh ruminal fluid, with this difference being greater during the first $24 \mathrm{~h}$ (Figure 1). However, treatment HIGH24 displayed greater $\mathrm{Vm}$ $(P<0.01)$ compared to treatments MODE24 or LOW24 regardless of fermentation substrate. In addition, both alfalfa and orchardgrass had the highest $(P<0.01) \mathrm{Vm}$ across treatments with an average of $345.7 \pm 14.40 \mathrm{~mL} / \mathrm{g}$. The interaction of treatment $\times$ fermentation substrate was significant $(P<0.01)$ for $L$ and $S$. Specifically, $L$ was highest $(P<0.01)$ for LOW24 when orchardgrass or guinea grass was used as fermentation substrates with an estimate of $22.29 \mathrm{~h}$. However, there was no difference in $L$ among treatments when cocuite was used as fermentation substrate. Furthermore, $S$ was lowest $(P<0.01)$ for treatment LOW24 regardless of fermentation substrates with an average of $0.018 \mathrm{~h}^{-1}$. However, $S$ reached highest $(P<0.01)$ values in most fermentation substrates when CONTROL was used as inoculum followed by HIGH24. 
Table 3: Parameters of the fermentation kinetics ( $V m, L$ and $S$ ) and in vitro dry matter digestibility at 24 and $72 \mathrm{~h}\left(\mathrm{IVDMD}_{24}, \mathrm{IVDMD}_{72}\right)$ for fresh inoculum or lyophilized inocula reactivated by 24 -h pre-incubation in one of three culture media

\begin{tabular}{|c|c|c|c|c|c|c|c|c|}
\hline \multirow[b]{2}{*}{ Inoculum type } & \multirow[b]{2}{*}{$\begin{array}{l}\text { Fermentation } \\
\text { substrate }\end{array}$} & \multicolumn{3}{|c|}{ Fermentation parameters ${ }^{A}$} & \multirow[b]{2}{*}{$\begin{array}{l}\operatorname{IVDMD}_{24} \\
(\mathrm{~g} / \mathrm{kg})\end{array}$} & \multirow[b]{2}{*}{$\begin{array}{c}\mathrm{IVDMD}_{72} \\
(\mathrm{~g} / \mathrm{kg})\end{array}$} & \multirow[b]{2}{*}{$\begin{array}{r}\% \text { gas } \\
\text { at } 72 \mathrm{~h}\end{array}$} & \multirow[b]{2}{*}{$\begin{array}{c}\% \text { IVDM at } \\
24 \mathrm{~h} / 72 \mathrm{~h}\end{array}$} \\
\hline & & $V m(m L / g)$ & $L(\mathrm{~h})$ & $S\left(h^{-1}\right)$ & & & & \\
\hline \multirow{4}{*}{ CONTROL } & Alfalfa & $435.75 a$ & $2.80 \mathrm{~d}$ & $0.043 a$ & $558.0 \mathrm{a}$ & $622.0 \mathrm{a}$ & 100.0 & 89.7 \\
\hline & Orchardgrass & $390.25 a$ & $4.89 d$ & $0.041 \mathrm{ba}$ & $538.0 \mathrm{a}$ & $618.0 \mathrm{a}$ & 100.0 & 87.1 \\
\hline & Cocuite & $346.25 a$ & $2.46 \mathrm{~d}$ & $0.044 a$ & 466.0ba & $508.0 \mathrm{dc}$ & 100.0 & 91.7 \\
\hline & Guinea grass & $376.35 a$ & $6.09 \mathrm{dc}$ & $0.036 \mathrm{cb}$ & $398.0 \mathrm{c}$ & $550.0 \mathrm{cb}$ & 99.9 & 72.4 \\
\hline \multirow{4}{*}{ LOW24 } & Alfalfa & $309.30 b$ & $7.31 b c$ & $0.019 \mathrm{e}$ & $432.0 \mathrm{cb}$ & $590.0 \mathrm{~b}$ & 94.9 & 73.2 \\
\hline & Orchardgrass & $303.20 \mathrm{~b}$ & $20.2 \mathrm{a}$ & $0.017 e$ & $314.0 \mathrm{~d}$ & $624.0 \mathrm{a}$ & 87.1 & 50.3 \\
\hline & Cocuite & $207.85 \mathrm{c}$ & $2.89 d$ & $0.020 \mathrm{e}$ & $324.0 \mathrm{~d}$ & $454.0 \mathrm{e}$ & 97.1 & 71.4 \\
\hline & Guinea grass & $244.10 \mathrm{c}$ & $24.38 \mathrm{a}$ & $0.016 \mathrm{e}$ & $180.0 f$ & $424.0 \mathrm{e}$ & 94.0 & 42.5 \\
\hline \multirow{4}{*}{ MODE24 } & Alfalfa & $319.45 b$ & $5.14 d c$ & $0.025 d$ & 482.0ba & $674.0 \mathrm{a}$ & 99.1 & 71.5 \\
\hline & Orchardgrass & $307.75 b$ & $10.32 \mathrm{bc}$ & $0.018 \mathrm{e}$ & $402.0 \mathrm{c}$ & $636.0 \mathrm{a}$ & 92.0 & 63.2 \\
\hline & Cocuite & $288.80 \mathrm{c}$ & $4.91 \mathrm{~d}$ & $0.025 d$ & $382.0 \mathrm{c}$ & $516.0 \mathrm{c}$ & 99.1 & 74.0 \\
\hline & Guinea grass & $236.90 \mathrm{c}$ & $10.12 b c$ & $0.021 \mathrm{ed}$ & $252.0 \mathrm{e}$ & $484.0 \mathrm{~d}$ & 96.1 & 52.1 \\
\hline \multirow{4}{*}{ HIGH24 } & Alfalfa & $367.15 a$ & $5.64 d c$ & $0.033 \mathrm{cb}$ & $524.0 \mathrm{a}$ & $630.0 \mathrm{a}$ & 99.9 & 83.2 \\
\hline & Orchardgrass & $333.00 \mathrm{~b}$ & $11.68 \mathrm{bc}$ & $0.039 \mathrm{ba}$ & $502.0 \mathrm{ba}$ & $656.0 \mathrm{a}$ & 99.9 & 76.5 \\
\hline & Cocuite & $323.25 b$ & $5.04 \mathrm{dc}$ & $0.030 \mathrm{dc}$ & $404.0 \mathrm{c}$ & $512.0 \mathrm{c}$ & 99.8 & 78.9 \\
\hline & Guinea grass & $307.75 b$ & $9.85 b c$ & $0.025 d$ & $324.0 \mathrm{~d}$ & $554.0 \mathrm{~b}$ & 98.5 & 58.5 \\
\hline \multirow{4}{*}{ Inoculum means } & CONTROLy & $387.15 a$ & $4.06 \mathrm{c}$ & $0.041 \mathrm{a}$ & $490.0 \mathrm{a}$ & $574.5 a$ & 100.0 & 85.3 \\
\hline & LOW24x & $266.11 \mathrm{c}$ & 13.70a & $0.018 d$ & $312.5 d$ & $523.0 \mathrm{~b}$ & 90.0 & 59.8 \\
\hline & MODE24w & $288.22 \mathrm{C}$ & $7.62 b$ & $0.023 c$ & $379.5 \mathrm{c}$ & $577.5 a$ & 98.1 & 65.7 \\
\hline & $\mathrm{HIGH} 24^{v}$ & $332.83 b$ & $8.05 b$ & $0.032 b$ & $438.5 b$ & $588.0 \mathrm{a}$ & 99.8 & 74.6 \\
\hline \multirow{4}{*}{ Forage means } & Alfalfa & $357.90 \mathrm{a}$ & $5.22 b$ & $0.030 \mathrm{a}$ & $499.0 \mathrm{a}$ & $629.0 \mathrm{a}$ & 99.8 & 79.3 \\
\hline & Orchardgrass & $333.50 a$ & $11.77 a$ & $0.029 a$ & $439.0 \mathrm{~b}$ & $633.5 a$ & 99.3 & 69.3 \\
\hline & Cocuite & $291.50 \mathrm{~b}$ & $3.83 b$ & $0.030 \mathrm{a}$ & $394.0 \mathrm{c}$ & $497.5 b$ & 99.8 & 79.2 \\
\hline & Guinea grass & $291.20 \mathrm{~b}$ & $12.61 \mathrm{a}$ & $0.025 b$ & $288.5 d$ & $503.0 \mathrm{~b}$ & 98.1 & 57.4 \\
\hline \multirow[t]{2}{*}{ SEMB } & & 14.40 & 1.290 & 0.0012 & 10.80 & 10.50 & & \\
\hline & Inoculum & 0.001 & 0.001 & 0.001 & 0.001 & 0.001 & & \\
\hline \multirow[t]{2}{*}{$P$-values } & Forage & 0.001 & 0.001 & 0.001 & 0.001 & 0.001 & & \\
\hline & Inoculum $\times$ forage & 0.0766 & 0.001 & 0.0002 & 0.0012 & 0.0001 & & \\
\hline
\end{tabular}

${ }^{\mathrm{A}} V m$ : maximum volume of gas; $L$ : lag phase; $S$ : rate of gas production.

${ }^{B}$ SEM: the largest standard error of the mean is reported.

a-f: Means in the same column with different superscripts are different $(P<0.01)$.

The treatment $\times$ fermentation substrate interaction was significant $(P<0.01)$ for IVDMD 24 and IVDMD 72 . Specifically, when alfalfa was used as fermentation substrate, IVDMD 24 
for treatments MODE24 and HIGH24 was similar $(P \geq 0.1)$ to CONTROL with an average of $521.3 \pm 10.8 \mathrm{~g} / \mathrm{kg}$. However, IVDMD 24 for alfalfa was lower $(P<0.01)$ for treatment LOW24 compared to CONTROL with estimates of 432.0 and $558.0 \pm 10.8 \mathrm{~g} / \mathrm{kg}$ for LOW and CONTROL, respectively. Likewise, IVDMD 72 for treatments MODE24 and HIGH24 were similar $(P \geq 0.1)$ to CONTROL with an average of $642.0 \pm 10.5 \mathrm{~g} / \mathrm{kg}$. However, IVDMD $_{72}$ for alfalfa was lower $(P<0.01)$ for LOW24 compared to CONTROL24 with estimates of 590 and $622.0 \pm 10.5 \mathrm{~g} / \mathrm{kg}$ for LOW24 and CONTROL, respectively. The lowest $(P<0.01)$ IVDMD $_{72}$ was observed for treatment LOW24 when cocuite was used as fermentation substrate with an average of $439.0 \pm 10.5 \mathrm{~g} / \mathrm{kg}$. Overall, regardless of fermentation substrate, there was a depression $(P<0.01)$ in IVDMD for LOW24 compared to any of the other treatments.

\section{Fermentation kinetics and IVDMD for inoculum reactivated by $12 \mathrm{~h}$ pre- incubation}

Figure 3 illustrates in vitro gas production for the CONTROL and inoculum reactivated by incubation for $12 \mathrm{~h}$. CONTROL displayed a faster and greater maximum gas production compared to HIGH12. In addition, Figure 4 illustrates gas production for each fermentation substrate. Alfalfa displayed the greatest and fastest maximum gas production compared to the rest of forages, with cocuite and guinea grass having the lowest values.

Figure 3: In vitro gas production for the control and the preserved inoculum reactivated by pre-incubation for $12 \mathrm{~h}$ in a culture medium

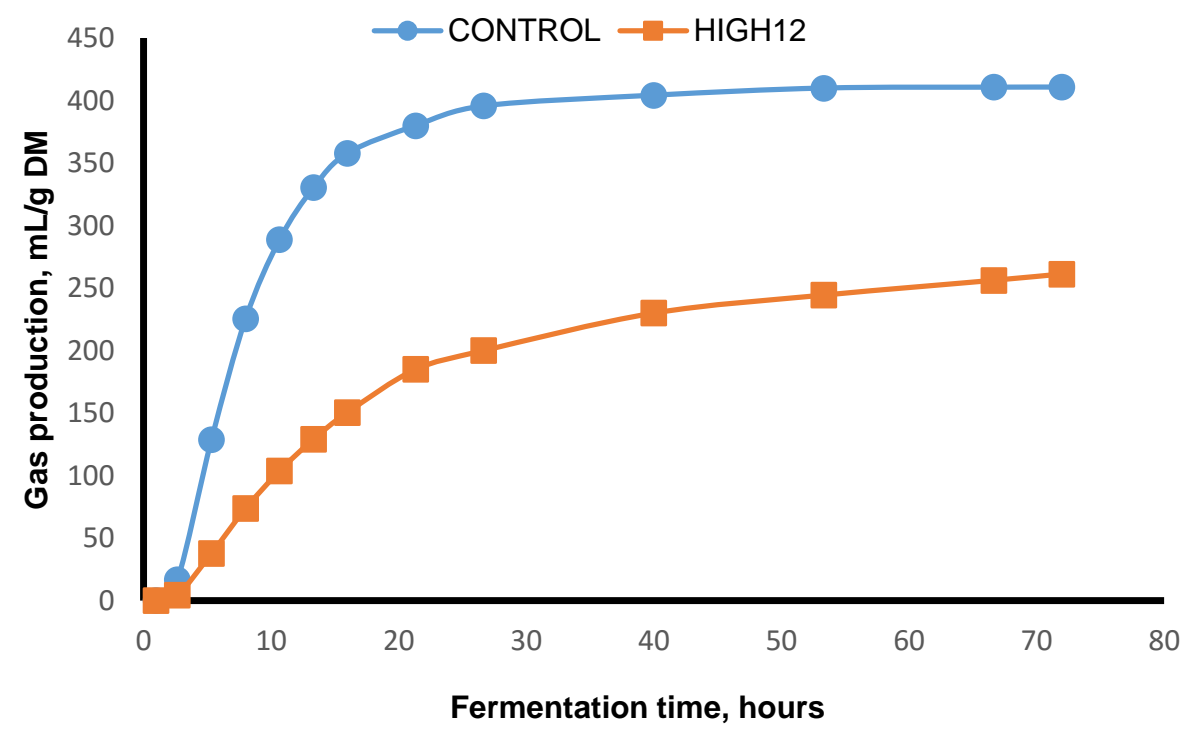

CONTROL $=$ fresh ruminal fluid; HIGH12, inoculum reactivated by $12 \mathrm{~h}$ pre-incubation in a basal culture solution, yeast extract, peptone from casein and carbohydrates. Control $=V m=410.80 \mathrm{~mL} / \mathrm{g}, L=5.42 \mathrm{~h}$, $S=0.032 \mathrm{~h}^{-1}$; HIGH12=Vm=264.97 mL/g, $L=4.29 \mathrm{~h}, S=0.017 \mathrm{~h}^{-1}$. 
Figure 4: In vitro gas production for four forages when values for fresh ruminal fluid and inoculum reactivated by pre-incubation for $12 \mathrm{~h}$ were averaged

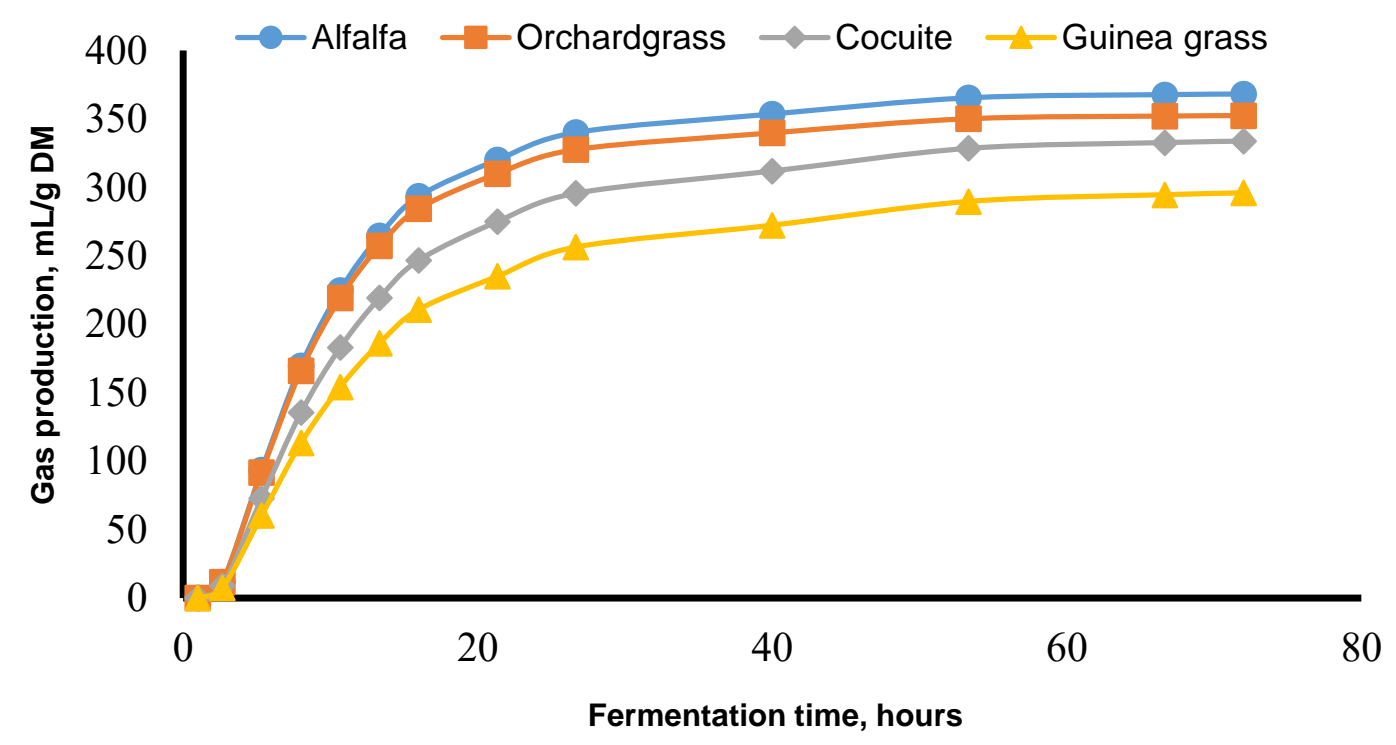

Alfafa: $V m=368.30 \mathrm{~mL} / \mathrm{g}, L=2.13 \mathrm{~h}, S=0.032 \mathrm{~h}^{-1}$; orchardgrass: $V m=352.51 \mathrm{~mL} / \mathrm{g}, L=9.19 \mathrm{~h}, S=0.033 \mathrm{~h}^{-1}$; cocuite: $V m=334.16 \mathrm{~mL} / \mathrm{g}, L=3.79 \mathrm{~h}, S=0.027 \mathrm{~h}^{-1}$; guinea grass: $V m=296.56 \mathrm{~mL} / \mathrm{g}, L=4.31 \mathrm{~h}, S=0.025 \mathrm{~h}^{-1}$.

Specifically, fermentation kinetics, IVDMD 24 and IVDMD 72 were affected by treatment and fermentation substrate (Table 4$). V m$ was greater $(P<0.01)$ for CONTROL compared to HIGH12, with estimates of 410.80 and $264.97 \pm 13.050 \mathrm{~mL} / \mathrm{g}$, respectively. The interaction of inoculum type $\times$ fermentation substrate was significant for $L(P<0.011)$; orchardgrass and alfalfa incubated in HIGH12 had the greatest and lowest $(P<0.01) L$, respectively; with estimates of 12.4 and $0.07 \pm 0.700 \mathrm{~h}$ for orchardgrass and alfalfa. Likewise, an interaction $(P<0.01)$ was detected for $S$; alfalfa incubated in CONTROL and cocuite incubated in HIGH12 had the greatest and lowest $S$, respectively; with estimates of 0.047 and $0.013 \pm 0.007 \mathrm{~h}^{-1}$ for alfalfa and cocuite. Regardless of forage type, the IVDMD $_{24}$ was greater for CONTROL compared to HIGH12 with estimates of 520.6 and $374.3 \pm 12.70 \mathrm{~g} / \mathrm{kg}$, respectively. There was an inoculum type $\times$ fermentation substrate interaction $(P<0.01)$ for IVDMD $_{72}$ with alfalfa and orchargrass incubated in CONTROL having the greatest IVDMD 72 , and cocuite and guinea grass having the lowest $\operatorname{IVDMD}_{72}$ values. 
Table 4: Parameters of fermentation kinetics ( $V m, L$ and $S$ ) and in vitro dry matter digestibility at 24 and $72 \mathrm{~h}\left(I V D M D_{24}, I V D M D_{72}\right)$ for fresh inoculum or lyophilized inoculum reactivated by $12 \mathrm{~h}$ pre-incubation in a nutrient-rich medium

\begin{tabular}{|c|c|c|c|c|c|c|c|c|}
\hline \multirow[b]{2}{*}{ Inoculum type } & \multicolumn{5}{|c|}{ Fermentation parameters ${ }^{\mathrm{A}}$} & \multirow[b]{2}{*}{$\begin{array}{l}I V D M D_{24} \\
(\mathrm{~g} / \mathrm{kg})\end{array}$} & \multirow[b]{2}{*}{$\%$ gas at $72 \mathrm{~h}$} & \multirow[b]{2}{*}{$\begin{array}{c}\% \text { IVDM at } 24 \\
\mathrm{~h}\end{array}$} \\
\hline & $\begin{array}{l}\text { Fementation } \\
\text { substrate }\end{array}$ & $V m(\mathrm{~mL} / \mathrm{g})$ & $L(\mathrm{~h})$ & $S\left(\mathrm{~h}^{-1}\right)$ & $\begin{array}{l}I V D M D_{24} \\
(\mathrm{~g} / \mathrm{kg})\end{array}$ & & & \\
\hline \multirow{4}{*}{ CONTROL } & Alfalfa & $457.33 \mathrm{~d}$ & $4.19 b$ & $0.047 f$ & $625.3 \mathrm{a}$ & $673.3 \mathrm{~d}$ & 100.0 & 92.9 \\
\hline & Orchardgrass & $409.96 c$ & $6.14 \mathrm{~b}$ & $0.042 \mathrm{e}$ & $594.6 \mathrm{a}$ & $678.6 \mathrm{~d}$ & 100.0 & 87.6 \\
\hline & Cocuite & $400.80 \mathrm{c}$ & $4.36 \mathrm{~b}$ & $0.041 \mathrm{e}$ & $463.9 \mathrm{~b}$ & $573.3 \mathrm{~b}$ & 100.0 & 80.9 \\
\hline & Guinea grass & $375.10 \mathrm{~b}$ & $7.00 \mathrm{~b}$ & $0.034 \mathrm{~d}$ & $398.6 \mathrm{c}$ & $551.9 \mathrm{~b}$ & 99.9 & 72.2 \\
\hline \multirow{4}{*}{ HIGH12 } & Alfalfa & $279.26 \mathrm{a}$ & $0.07 \mathrm{a}$ & $0.017 \mathrm{~b}$ & $461.3 b$ & $619.9 \mathrm{c}$ & 94.7 & 74.4 \\
\hline & Orchardgrass & $295.06 \mathrm{a}$ & $12.24 \mathrm{c}$ & $0.024 \mathrm{c}$ & $407.9 \mathrm{~b}$ & $657.3 \mathrm{~d}$ & 97.7 & 62.1 \\
\hline & Cocuite & $267.53 \mathrm{a}$ & $3.23 \mathrm{ab}$ & $0.013 \mathrm{a}$ & $350.6 \mathrm{c}$ & $478.6 \mathrm{a}$ & 82.9 & 73.3 \\
\hline & Guinea grass & $218.03 \mathrm{a}$ & $1.63 \mathrm{ab}$ & $0.015 \mathrm{ab}$ & $278.6 \mathrm{~d}$ & $459.9 \mathrm{a}$ & 90.2 & 60.6 \\
\hline \multirow{2}{*}{$\begin{array}{l}\text { Inoculum } \\
\text { means }\end{array}$} & CONTROL & $410.80 \mathrm{~b}$ & 5.42 & $0.041 b$ & $520.6 \mathrm{a}$ & $619.3 b$ & 100.0 & 84.1 \\
\hline & HIGH12 & $264.97 \mathrm{a}$ & 4.29 & $0.017 \mathrm{a}$ & $374.3 \mathrm{~b}$ & $553.9 \mathrm{a}$ & 93.1 & 67.6 \\
\hline \multirow{4}{*}{ Forage means } & Alfalfa & $368.30 \mathrm{~b}$ & $2.13 \mathrm{a}$ & 0.032 & $543.3 \mathrm{a}$ & $646.6 \mathrm{~b}$ & 99.9 & 84.0 \\
\hline & Orchardgrass & $352.51 \mathrm{~b}$ & $9.19 \mathrm{c}$ & $0.033 \mathrm{c}$ & $501.3 \mathrm{a}$ & $667.9 \mathrm{~b}$ & 99.8 & 75.1 \\
\hline & Cocuite & $334.16 \mathrm{~b}$ & $3.79 \mathrm{ab}$ & $0.027 \mathrm{~b}$ & $407.3 \mathrm{~b}$ & $525.9 \mathrm{a}$ & 99.5 & 77.4 \\
\hline & Guinea grass & $296.56 a$ & $4.31 \mathrm{~b}$ & $0.025 \mathrm{a}$ & $338.6 \mathrm{c}$ & $505.9 \mathrm{a}$ & 99.2 & 66.9 \\
\hline $\mathrm{SEM}^{\mathrm{B}}$ & & 13.050 & 0.700 & 0.0007 & 12.70 & 7.80 & & \\
\hline \multirow{3}{*}{$P$-values } & Inoculum type & 0.0001 & 0.0359 & 0.0001 & 0.0001 & 0.0001 & & \\
\hline & Forage species & 0.0003 & 0.0001 & 0.0001 & 0.0001 & 0.0001 & & \\
\hline & $\begin{array}{l}\text { Inoculum type } \\
\times \text { forage } \\
\text { species }\end{array}$ & 0.1200 & 0.0001 & 0.0001 & 0.0295 & 0.0006 & & \\
\hline
\end{tabular}

${ }^{\mathrm{A}}$ Gas production model was Schofield et al. (1994): Volume of gas $=\frac{V m}{1+\exp (2-4 \times S \times(t-L))}$

where $V m$ is maximum volume of gas; $L$ is the lag phase, and $S$ is the rate of gas production.

${ }^{B}$ SEM: the largest standard error of the mean is reported.

a-f: Means within column with at least 1 letter in common are not different $(P<0.01)$.

\section{Discussion}

\section{Ruminal fluid sampling and the use of glycerol as a cryoprotectant}

Studies ${ }^{(31,32,33)}$ have found differences in in vitro fermentation patterns between ruminal fluid from different donors. The source of ruminal fluid can influence in vitro fermentation and digestibility trials ${ }^{(31,39)}$. Differences in fermentation patterns among animals observed by those researchers can be partially attributed to differences in the composition of the established bacterial community among host animals ${ }^{(40,41)}$. Therefore, in the present study, ruminal fluid samples from three donors were pooled to obtain a representative sample to prevent bias due to ruminal fluid source. 
The use of glycerol improves the preservation of the ruminal bacterial community ${ }^{(12,13,14)}$. Benefits of glycerol may be explained by peripheral vitrification providing protection to the bacterial cytoplasmic membranes from potential damage that can be caused by ice crystal formation $^{(42)}$. More specifically, glycerol penetrates the cells, which can then protect them from damage by maintaining a semi-fluid state ${ }^{(43,44)}$. Consequently, the use of glycerol not only protects the integrity and viability of the ruminal bacterial cells, but may also prevent degradation of the microbial $\mathrm{DNA}^{(13)}$.

\section{Fermentation kinetics and IVDMD of preserved inocula}

In vitro fermentation kinetics and IVDMD revealed differences between fresh and lyophilized ruminal fluid. When compared to fresh ruminal fluid, the greatest depression in fermentation kinetic parameters was observed when lyophilized inocula were reactivated in media without sugars or growth promoters. These observations are in line with other studies ${ }^{(15)}$, indicating a depression on fermentation parameters with frozen inocula, which can be explained by a decrease in microbial activity due to microbial death or nutrient limitation ${ }^{(9)}$. In addition, researchers have reported ${ }^{(8)}$ that protein degradation rates with preserved ruminal microorganisms were 4 to 8 times slower than when using fresh ruminal fluid. Furthermore, the use of inoculum preserved through freezing affects fermentation parameters during the first hours of fermentation ${ }^{(30)}$, and deep freezing may represent a better preservation method compared to freezing at $-20{ }^{\circ} \mathrm{C}$. Consequently, in agreement with recent reports, the reactivation of preserved bacteria is one of the most critical steps in obtaining active and effective microorganisms for in vitro fermentation trials $^{(21,22,23)}$.

In this study, compared to fresh ruminal fluid, the negative effects of lyophilization on fermentation kinetics and IVDMD was less severe when ruminal inocula were reactivated in a nutrient-rich medium including a basal culture solution, growth promoters and sugars. These observations indicate that growth promoters such as yeast extract and peptone from casein, and carbohydrates such as glucose, cellobiose and starch enhance the reactivation of ruminal microorganisms, thus, improving in vitro fermentation. The need for yeast extract in the medium for adequate bacterial reactivation and growth may be attributed to the absence of the genes for the synthesis of some proteinogenic amino acids such as arginine and asparagine in the genome of some ruminal bacterial species ${ }^{(45,46)}$, which indicates that these amino acids contained in the yeast extract need to be included in the medium. Additionally, peptone from casein and carbohydrates provide readily available nitrogen and energy stimulating microbial reactivation, growth and activity ${ }^{(19,47)}$. It is interesting to note the different patterns (gas production at different time points) among the fermentation curves, which suggests that different microbial populations may be acting on the substrates at each fermentation time point. Further research should aim at investigating shifts in the structure of the microbial community ${ }^{(48,49)}$ using techniques 
such as high-throughput DNA sequencing ${ }^{(50,51,52)}$, which allows a broad evaluation of the profile microbial community from highest to lowest taxonomic levels.

It has been found that, in comparison to fresh ruminal fluid, digestibility of alfalfa decreased $17.63 \%$ when using frozen inoculum or lyophilized inoculum reactivated by $24 \mathrm{~h}$ pre-incubation in McDougall's solution ${ }^{(9)}$. In contrast to previous observations ${ }^{(9)}$, in the present study, IVDMD 72 was not affected when using lyophilized inoculum reactivated by $24 \mathrm{~h}$ pre-incubation in a nutrient-rich medium; indicating that, compared to the use of McDougall's solution, using a nutrient-rich medium containing a wider range of nutrients represents a better approach for stimulating the reactivation and activity of ruminal microorganisms.

When averaged across fermentation substrates (i.e. alfalfa, orchard grass, cocuite and guinea grass), the IVDMD for any of the reactivated inocula was negatively affected, compared to the values obtained with the control. However, within lyophilized inocula, the reactivation by $24 \mathrm{~h}$ pre-incubation in a nutrient-rich medium displayed the best performance. In addition, when the inoculum was reactivated by $12 \mathrm{~h}$ pre-incubation, IVDMD values were lower compared to the control fresh ruminal fluid. It is important to note that, at $72 \mathrm{~h}$ fermentation all forages but cocuite reached almost $100 \%$ of the total gas produced. This indicates that $72 \mathrm{~h}$-fermentation rates are not suitable for measuring the effectiveness of the treatments, which also suggests that a better approach would be to measure fermentation rates and IVDMD at 24 or $48 \mathrm{~h}$ of fermentation.

\section{Effect of fermentation substrate on fermentation kinetics and IVDMD}

The use of fermentation substrates with a wide range of nutrient composition facilitated the evaluation of our hypothesis under different scenarios. Overall, our results revealed that forages from temperate zones, namely alfalfa and orchardgrass, had higher $\mathrm{Vm}$ and IVDMD compared to their counterparts from the tropical regions. These observations were likely due to differences in the structural components of the plant cell-wall existing between forages from temperate and those from tropical zones ${ }^{(53)}$.

Furthermore, alternative inoculum sources have been suggested for in vitro fermentations. One of these sources is ruminant feces; however, results have been inconsistent. For example, fecal inoculum has been demonstrated to be effective for in vitro gas production studies ${ }^{(54)}$; nonetheless, fecal inoculum from sheep was not comparable to fresh ruminal fluid when evaluating in vitro dry matter digestibility ${ }^{(55)}$. In addition, other studies, have revealed that fecal inoculum does not perform as good as ruminal fluid in in vitro fermentation techniques ${ }^{(55,56)}$, which may be due to differences in the bacterial populations between the rumen and the lower gastrointestinal tract ${ }^{(57)}$. 


\section{Conclusions and implications}

In vitro fermentation kinetics and IVDMD were affected by lyophilization of ruminal fluid. In most cases, fermentation parameters $V m, L$ and $S$ were negatively affected when lyophilized ruminal inoculum was used. However, when glycerol was added to the lyophilized ruminal inocula and was reactivated for $24 \mathrm{~h}$ in a pre-incubation nutrient-rich medium, including growth promoters and sugars, the negative effects of lyophilization on in vitro fermentation kinetics and IVDMD were less severe. As expected, alfalfa and orchardgrass had higher $V m$ and IVDMD compared to cocuite and guinea grass. Results reported in this study should provide new insights into reactivation of preserved ruminal inoculum as well as its utilization in in vitro fermentation and digestion trials for laboratories with limited access to fistulated animals or fresh ruminal fluid. Future research should explore changes in rumen microbial populations during in vitro fermentations using high-throughput DNA sequencing to understand how shifts in the microbial profiles lead to the different patterns observed among fermentation curves.

\section{Literature cited:}

1. Narvaez N, Wang Y, Xu Z, McAllister T. Effects of hops on in vitro ruminal fermentation of diets varying in forage content. Livest Sci 2011;138:193-201.

2. Anele UY, Refat B, Swift ML, Zhao YL, Doublier C, McAllister TA, et al. In vitro ruminal fermentation of ground and dry-rolled barley grain differing in starch content. Anim Feed Sci Technol 2015;203:88-94.

3. Pal K, Patra AK, Sahoo A, Kumawat PK. Evaluation of several tropical tree leaves for methane production potential, degradability and rumen fermentation in vitro. Livest Sci 2015;180:98-105.

4. Bochi-Brum O, Carro MD, Valdés C, González JS, López S. In vitro digestibility of forages and concentrates: effect of diet on donor animals. Arch Zoot 1999;48:51-61.

5. Bueno ICS, Cabral LS, Gobbo SP, Louvandini H, Vitti DM, Abdalla L. Influence of inoculum source in a gas production method. Anim Feed Sci Technol 2005;124:95105.

6. Mould FL, Kliem KE, Morgan R, Mauricio RM. In vitro microbial inoculum: A review of its function and properties. Anim Feed Sci Technol 2005;123:31-50.

7. Luchini ND, Broderick GA, Combs DK. In vitro determination of ruminal protein degradation using freeze-stored ruminal microorganisms. J Anim Sci 1996;74:24882499. 
8. Luchini ND, Broderick GA, Combs DK. Preservation of ruminal microorganisms for in vitro determination of ruminal protein. J Anim Sci 1996;74:1134-1143.

9. Meneses M, Madrid SJ, Hernández RF, Megias MD. Evaluación de diferentes métodos de conservación del líquido ruminal para pruebas in vitro. Sociedad Española de Ovinotecnia y Caprinotecnia 2000;25:315-317.

10. Malik KA. Cryopreservation of bacteria with special reference to anaerobes. World J Microbiol Biotechnol 1991;7:629-632.

11. Perry SF. Freeze-drying and cryopreservation of bacteria. Mol Biotechnol 1998;9:59-64.

12. Rojas-Tapias D, Ortiz-Vera M, Rivera D, Kloepper J, Bonilla R. Evaluation of three methods for preservation of Azotobacter chroococcum and Azotobacter vinelandii. Universitas Scientiarum 2013;18(2):129-139.

13. McKain N, Genc B, Snelling TJ, Wallace RJ. Differential recovery of bacterial and archaeal 16S rRNA genes from ruminal digesta in response to glycerol as cryoprotectant. J Microbiol Methods 2013;95:381-383.

14. Fliegerova K, Tapio I, Bonin A, Mrazek J, Callegari ML, Bani P, et al. Effect of DNA extraction and sample preservation method on rumen bacterial population. Anaerobe 2014;29:80-84.

15. Hervas G, Frutos P, Giráldez FJ, Mora MJ, Fernández B, Mantecón AR. Effect of preservation on fermentative activity of ruminal fluid inoculum for in vitro gas production techniques. Anim Feed Sci Technol 2005;124:107-118.

16. NRC. Nutrient requirements of beef cattle. 7th rev. ed. Washington, DC; Natl Acad Press; 2000.

17. Beaudet V, Gervais R, Graulet B, Nozière P, Doreau AM, Fanchone A, et al. Effects of dietary nitrogen levels and carbohydrate sources on apparent ruminal synthesis of some B vitamins in dairy cows. J Dairy Sci 2016;99:2730-2739.

18. Stern MD, Hoover WH. Methods for determining and factors affecting rumen microbial protein synthesis: a review. J Anim Sci 1979;49:1590-1603.

19. Russell JB. Rumen Microbiology and its role in ruminant nutrition. Russell JB editor. Ithaca, NY, USA: Publ. Co; 2002.

20. Fernando SC, Purvis II HT, Najar FZ, Sukharnikov L, Nagaraja TG, Krehbiel CR, et al. Rumen microbial population dynamics during adaptation to high-grain diet. Appl Environ Microbiol 2010;76:7482-7490. 
21. Muller JA, Stanton C, Sybesma W, Fitzgerald GF, Ross RP. Reconstitution conditions for dried probiotic powders represent a critical step in determining cell viability. J Appl Microbiol 2012;108:1369-1379

22. Hoefman S, Van Hoorde K, Boon N, Vandamme P, De Vos P, Heylen K. Survival or revival: long-term preservation induces a reversible viable but non-culturable state in methane-oxidizing bacteria. PLoS ONE 2012;7(4):e34196.

23. Miyamoto-Shinohara Y, Sukenobe J, Imaizumi T, Nakahara T. Survival of freezedried bacteria. J Gen Appl Microbiol 2008;54:9-24.

24. Association of Official Analytical Chemists. 'Official Methods of Analysis.' 17th ed. (AOAC). Arlington, VA, USA. 2000.

25. Goering HK, Van Soest PJ. Forage fiber analysis (apparatus, reagents, procedures and some applications). Agr Res Serv, USDA, Washington, DC, USA, Agriculture Handbook No 379; 1970.

26. Witham FH, Blaydes DF, Devlin RM. Experiments in plant physiology. Van Nostrand New York, USA: Reinhold Company; 1971.

27. Udén P, Robinson PH, Mateos GG, Blank R. Use of replicates in statistical analyses in papers submitted for publication in Animal Feed Science and Technology. Anim Feed Sci Technol 2012;171:11-15.

28. Castro-Montoya J, De Campeneere S, Van Ranst G, Fievez V. Interactions between methane mitigation additives and basal substrates on in vitro methane and VFA production. Anim Feed Sci Technol 2012;176:47-60.

29. Ferraro SM, Mendoza GD, Miranda LA, Gutiérrez CG. In vitro ruminal fermentation of glycerol, propylene glycol and molasses combined with forages and their effect on glucose and insulin blood plasma concentrations after an oral drench in sheep. Anim Feed Sci Technol 2016;213:74-80.

30. Prate A, de Oliveira JA, Abecia L, Fondevila M. Effects of preservation procedures of rumen inoculum on in vitro microbial diversity and fermentation. Anim Feed Sci Technol 2010;150:186-193.

31. Johnson RR. Techniques and procedures for in vitro and in vivo rumen studies. $\mathrm{J}$ Anim Sci 1966;25:855-875.

32. Nelson BD, Ellzey HD, Montgomery C, Morgan EB. Factors affecting the variability of an in vitro rumen fermentation technique for estimating forage quality. J Dairy Sci 1972;55:358-366.

33. Pehrson A, Faber WE. Individual variation of in vitro dry matter digestibility in moose. J Range Manage 1994;47:392-394. 
34. Jones GA, Pickard MD. Effect of titanium citrate as reducing agent on growth of rumen bacteria. Appl Environ Microbiol 1980;39:144-1147.

35. Theodorou MK, Williams BA, Dhanoa MS, McAllan AB, France J. A simple gas production method using a pressure transducer to determine the fermentation kinetics of ruminant feeds. Anim Feed Sci Technol 1994;48:185-197.

36. Antúnez G, Cajarville C, Britos A, González A, Repetto JL. Ruminal inoculum activity in cattle supplemented with corn grain at different daily frequencies: evaluation using the in vitro gas-production technique. Anim Prod Sci 2014;54:1662-1664.

37. Schofield P, Pitt RE, Pell AN. Kinetics of fiber digestion from in vitro gas production. J Anim Sci 1994;72:2980-2991.

38. SAS. SAS/STAT User's guide (Release 9.1). SAS Institute Inc., Cary, NC, USA, 2004.

39. Williams BA. Cumulative gas-production techniques for forage evaluation. In: Forage evaluation in ruminant nutrition. Givens DI, et al. editors. Wallingford. UK: CAB International; 2000.

40. Weimer PJ, Stevenson DM, Mantovani HC, Man SLC. Host specificity of the ruminal bacterial community in the dairy cow following near-total exchange of ruminal contents. J Dairy Sci 2010;93:5902-5912.

41. Weimer PJ, Stevenson DM, Mertens DR. Shifts in bacterial community composition in the rumen of lactating dairy cows under milk fat-depressing conditions. J Dairy Sci 2010;93:265-278.

42. Kim SJ, Yim JH. Cryoprotective properties of exopolysaccharide (P-21653) produced by the Antarctic bacterium, Pseudoalteromonas artica KOPRI 21653. J Microbiol 2007;46:510-514.

43. Hubálek Z. Protectant used in the cryopreservation of microorganisms. Cryobiology 2003;46:205-229.

44. Hancocks NH, Thomas CR, Stocks SM, Hewitt CJ. An investigation into the preservation of microbial cell banks for $\alpha$-amilase production during 51 fed-batch Bacillus licheniformis fermentations. Biotechnol Lett 2010;32:1405-1412.

45. Geissinger O, Herlemann DPR, Morschel E, Maier UG, Brune A. The ultramicrobacterium "Elusimicrobium minutum" gen. nov., sp. nov., the first cultivated representative of the termite group I phylum. Appl Environ Microbiol 2009;75:2831-2840.

46. Herlemann DPR, Geissinger O, Ikeda-Ohtsubo W, Kunin V, Sun H, Lapidus A, et al. Genomic analysis of "Elusimicrobium minutum," the first cultivated 
representative of the phylum "Elusimicrobia" (formerly termite group 1). Appl Environ Microbiol 2009;75:2841-2849.

47. McAllister TA, Bae HD, Jones GA, Cheng KJ. Microbial attachment and feed digestion in the rumen. J Anim Sci 1994;72:3004-3018.

48. Castillo-Lopez E, Moats J, Aluthge ND, Ramirez Ramirez HA, Christensen D, Mutsvangwa $\mathrm{T}$ et al. Effect of partially replacing a barley-based concentrate with flaxseed-based products on the rumen bacterial population of lactating Holstein dairy cows. J Appl Microbiol 2017;124:42-57.

49. Castillo-Lopez E, Jenkins CJR, Aluthge ND, Westom T, Fernando SC, Kononoff PJ. The effects of regular or low-fat distillers grains and solubles on rumen methanogenesis and the rumen bacterial community. J Appl Microbiol 2017;123:1381-1395.

50. Danielsson R, Dicksved J, Sun L, Gonda H, Muller B, Schnurer A, Bertilsson J. Methane production in dairy cows correlates with rumen methanogenic and bacterial community structure. Front Microbiol 2017;8:226.

51. Anderson CL, Schneider CJ, Erickson GE, MacDonald JC, Fernando SC. Rumen bacterial communities can be acclimated faster to high concentrate diets than currently implemented feedlot programs. J Appl Microbiol 2016;120:588-599.

52. Castillo-Lopez E, Klopfenstein TJ, Anderson C, Alugthge ND, Fernando SC, Kononoff PJ. Effect of feeding dried distillers grains with solubles on rumen biohydrogenation, intestinal fatty acid profile and gut microbial diversity evaluated through DNA pyro- sequencing. J Anim Sci 2014;92:733-743.

53. Saydack AH, Grant CC, Smit IP, Vermeulen WJ, Baard J, Zambatis N. Climate and vegetation in a semi-arid savanna: Development of a climate-vegetation response model linking plant metabolic performance to climate and the effects on forage availability for large herbivores. Koedoe 2012;54:1-12.

54. Posada SL, Noguera RR, Segura JA. Ruminant feces used as inoculum for the in vitro gas production technique. Rev Colomb Cienc Pecu 2012;25:592-600.

55. Hughes M, Mlambo V, Lallo CHO, Jennins PGA. Potency of microbial inocula from bovine faeces and rumen fluid for in vitro digestion of different tropical forage substrates. Grass Forage Sci 2012;67:263-273.

56. Zicarelli F, Calabro S, Cutrignelli MI, Infascelli F, Tudisco R, Bovera F et al. In vitro fermentation characteristics of diets with different forage/concentrate ratios: comparison of rumen and faecal inocula. J Sci Food Agric 2011;91:1213-1221.

57. Castillo-Lopez E, Klopfenstein TJ, Fernando SC, Kononoff PJ. In vivo determination of rumen undegradable protein of dried distillers grains with solubles and evaluation of duodenal microbial crude protein flow. J Anim Sci 2013;91:924-934. 